\title{
Differential gene expression in sugarcane roots infested by root froghopper
}

\section{Expressão gênica diferencial em raízes de cana-de-açúcar infestadas por cigarrinha-das-raízes}

\author{
Lúcia LOPES ${ }^{1 ; 2}$; Aline Andrucioli BELESINI ${ }^{3}$; Eliane GRISOTO ${ }^{4}$; Juliana da Silva VANTINI ${ }^{5}$; \\ Renata Izabel Dozzi TEZZA ${ }^{6}$; Maria Inês Tiraboschi FERRO ${ }^{7}$ \\ ${ }^{1}$ Parte da dissertação de mestrado da primeira autora; Pesquisa financiada pela CAPES e FAPESP \\ ${ }^{2}$ Bióloga; Mestre em Agronomia: Genética e Melhoramento de Plantas; Instituição atual: USP; lucialopes@usp.br \\ ${ }^{2}$ Autor para correspondência (Corresponding author): Lúcia Lopes; Mestre em Genética e Melhoramento de Plantas; \\ Instituição atual: USP; Departamento: Genética; Laboratório: Genética e Biologia Molecular de Fungos; Endereço \\ completo da instituição: Av. Bandeirantes, 3900, Monte Alegre - Ribeirão Preto - SP - Brasil, CEP: 14049-900; \\ lucialopes@usp.br \\ ${ }^{3}$ Bióloga; Instituição: UNESP; alinebelesini@yahoo.com.br \\ ${ }^{4}$ Bióloga; Instituição: USP; egrisoto@usp.br \\ ${ }^{5}$ Bióloga; Instituição: UNESP; juvantini@yahoo.com.br \\ ${ }^{6}$ Tecnóloga em processamento de dados; Mestre em Agronomia: Genética e Melhoramento de Plantas; \\ Instituição: CREBIO, UNESP Jaboticabal, SP; renata25@fcav.unesp.br \\ ${ }^{7}$ Bióloga; Mestre e Doutora em Genética; Instituição: UNESP; mitferro@fcav.unesp.br
}

Recebido em: 11-02-2014; Aceito em: 19-11-2014

\begin{abstract}
Currently, sugarcane (Saccharum spp.) has been threatened by infestation of root froghopper (Mahanarva fimbriolata) and concern about its harmful effects is growing, due to the increase of environmental conditions favorable to the development of this pest, such as the harvest system expansion, in which there is no burning of sugarcane straw. The cDNA-AFLP technique was performed in order to identify the Differentially Expressed Fragments (DEF) in roots of sugarcane infested by root froghopper nymphs. Thus, plants of a susceptible variety (SP80-1816) and a resistant variety ("least infested") (SP83-5073) were grown and subsequently infested. Samples of roots were collected and frozen every $1,2,7$ and 14 days of infestation. The subsequent analysis by cDNA-AFLP technique from seven combinations of primers allowed the observation of 37 fragments, which were sequenced and revealed similarities to proteins involved in various activities, such as DNA transposition, amino acid transport and gene transcription, in addition to other proteins without sequence similarity to proteins of known function. The alignments show similarities to expressed genes and it is possible to consider that the character of resistance is related to a combined action of several genes; in addition, some of the fragments obtained do not show similarities and may have important roles in the mechanism of resistance.
\end{abstract}

Additional keywords: cDNA-AFLP; Mahanarva fimbriolata; Saccharum spp.

\begin{abstract}
Resumo
Atualmente a cana-de-açúcar (Saccharum spp.), tem sido ameaçada pela infestação por cigarrinhadas-raízes (Mahanarva fimbriolata) e a preocupação com efeitos danosos por ela ocasionados são crescentes, em função do aumento de condições ambientais favoráveis ao desenvolvimento dessa praga, devido ao sistema de colheita em expansão, em que não há a queima da palhada. A fim de identificar Fragmentos Diferencialmente Expressos (FDE) em raízes de cana-de-açúcar infestadas por ninfas de cigarrinha, foi realizada a técnica de cDNA-AFLP. Assim, foram cultivadas e posteriormente infestadas, plantas de uma variedade suscetível (SP80-1816) e de uma variedade resistente ("menos infestada") (SP83-5073). As amostras das raízes foram coletadas e congeladas a cada 1, 2, 7 e 14 dias de infestação. A partir de 7 combinações de oligonucleotídeos foram obtidos 37 fragmentos, os quais foram sequenciados e revelaram similaridades com proteínas envolvidas em diferentes atividades, como a transposição de DNA, o transporte de aminoácidos e a transcrição gênica, além de outras proteínas sem similaridade encontrada. Os alinhamentos apresentam similaridades para os genes expressos e é possível considerar que o caráter de resistência esteja relacionado a uma ação conjunta de diversos genes, além disso, alguns dos fragmentos obtidos não apresentam similaridades e podem exercer importante papel no mecanismo de resistência.
\end{abstract}

Palavras-chave adicionais: cDNA-AFLP; Mahanarva fimbriolata; Saccharum spp. 


\section{Introduction}

Sugarcane is a graminaceous crop of great global importance, and its economic aspects are related to the several products originated from it, such as ethanol, a clean and renewable fuel, sugar and cachaça, besides the consequent creation of jobs related to this sector. Thus, the crop is increasing in Brazil, and its expected growth area in the country should be around 408 thousand hectares. In this regard, an estimated increase of $13.61 \%$ in sugar production is expected, compared to the 38.34 million tons of the previous harvest. Ethanol production is also estimated at 25.77 billion liters (CONAB, 2013).

Sugarcane can be harvested after field burning, in which there is carbon dioxide release and organic matter combustion, which facilitates manual cutting, or it can be performed through mechanical harvesting, in which there is no field burning. This latest harvest mode with raw sugarcane allows straw accumulation, so that a new environment is formed by the accumulation of organic matter, as the sugarcane is not burnt, influencing the occurrence of pests and diseases (ALMEIDA et al., 2003), including the root froghopper (Mahanarva fimbriolata).

In the São Paulo State, the State Law $11.241 / 02$, regulated by the State Decree $47.700 / 03$, requires that, by the year of $2021,100 \%$ of sugarcane mechanizable areas shall be harvested without sugarcane field burning. The environment provided by sugarcane raw cutting, such as humidity increase, favors the development of some pests, such as the root froghopper (M. fimbriolata). So, the importance of this pest has increased in the São Paulo State, especially in places with high temperatures. Root froghoppers are plant sucking insects, belonging to the Hemiptera order and the Cercopidae family, which suck the sap from roots and aerial parts of plants. Currently, most of the cultivated varieties are susceptible to the plague, causing yield losses as result of the attack (MACEDO et al., 2006), and in order to control it, chemical, cultural and biological control measures may be recommended. The $M$. fimbriolata females lay eggs in the straw layer, near to the soil, and nymphs hatch from the eggs and seek young roots, to feed themselves on xylem sap (GUIMARÃES, 2007). Regarding the consequences of the root froghopper attack, nymphs causes physiological disorders in the plants, since the stings reach root tracheal elements and damage it, impeding or preventing the flow of water and nutrients (GARCIA et al., 2007). Despite the reduction in sugarcane productivity and quality cane under root froghopper attack, few studies have focused on the relation between this plague and the sugarcane, and thus there is little information regarding sugarcane varieties resistance against root froghoppers, especially when it comes to differential gene expression.

The cDNA-AFLP technique was used in this study in order to enable DEF obtaining in the resistant variety over the susceptible. This technique is based on the AFLP technique, as described by VOS et al. (1995). However, cDNA is used instead of genomic DNA, and it has been used to identify differentially expressed genes in plants (LESTARI et al., 2006), as it is a sensitive and reproducible technique for gene detection (BACHEM et al.,1998). Furthermore, it can be used in the investigation of a wide variety of tissue types, developmental stages and time intervals that can be compared simultaneously (ALBA et al., 2004). According to MUTTON et al. (2012), the cDNAAFLP technique was used by GUIMARÃES (2007) in a study of the differential expression of sugarcane roots in response to root froghoppers attack, and differentially expressed sequences obtained showed similarity with cDNAs from other plants that appear to be related to defense mechanisms against biotic and abiotic stress. This technique has, among its advantages, the use of small cDNAs amounts and the fact that no previous knowledge is required on the sequences under study. In this study a molecular approach was used through cDNA-AFLP technique, in order to identify differentially expressed genes in sugarcane roots infested with $M$. fimbriolata nymphs.

\section{Material and methods}

Single bud setts of SP80-1816 (susceptible, SILVA et al. 2005; DINARDO-MIRANDA, 2004) and SP83-5073, resistant ("less infested," DINARDO-MIRANDA, 2003) varieties were planted in $300 \mathrm{~mL}$ plastic disposable cups containing a vermiculite substrate mixture (Plantmax HT $\AA$, Eucatex). These were irrigated daily up to field capacity. Thus, the experiment was conducted with 4 plants for each variety, and its respective controls for each of the four days of infestation, totaling 64 plants. The plants were kept in a greenhouse since planting, and in the 97th day were sent for acclimation for 3 days in acclimatized rooms with $25 \pm 1{ }^{\circ} \mathrm{C}$ temperature, $70 \% \pm 10 \%$ relative humidity and 14 hours photoperiod. Later, they were infested by third instar nymphs of $M$. fimbriolata. The nymphs were raised according to what was described by GARCIA et al. (2006). The third instar nymphs infestation was performed at 100 days after sugarcane varieties planting, with a brush, using ten nymphs per plant. The foam produced by the nymphs was transferred with them, in order to ensure survival after infestation. The presence of adults was monitored daily and individuals found were immediately discarded, so the effect of 
adults was not addressed in this study.

Root samples were collected at 1, 2, 7 and 14 days after infestation, and control plants were used for each treatment. After collection, the material was carefully cleaned in water, properly labeled and stored in liquid nitrogen and then in a $80{ }^{\circ} \mathrm{C}$ freezer. Extraction of total RNA was iniciated in 2012, starting from $0.6 \mathrm{~g}$ of root samples derived from aliquots of same mass, originating from the four sample replicates, using the "illustra RNAspin Mini RNA isolation" (GE Healthcare) kit and following the manufacturer's recommendations. Total RNA was resuspended in RNase free water and stored at $-80^{\circ} \mathrm{C}$. The complementary DNA synthesis (cDNA) was performed from $5 \mu \mathrm{g}$ of the total RNA treated with DNAse I, using Revertaid ${ }^{T M} H$ Minus First Strand cDNA Synthesis Kit (Fermentas) for the first and second band synthesis, according to instructions from the manufacturer. The cDNA purification was carried out using phenol/chloroform/isoamyl alcohol (25:24:1) method, described by SAMBROOK et al. (1989). The cDNA concentration and purity was determined by NanoDrop ND-1000 (Thermo Fisher Scientific Inc.) spectrophotometer absorbance quantification.

For the CDNA-AFLP technique, the AFLP $\AA$ Plant Mapping Kit (Regular Plant Genomes), made by PE-Applied Biosystems, Inc., CA, USA (1997) was used, according to manufacturer's instructions. The cDNA cleavage was performed using EcoRI and Msel restriction enzymes, and subsequently $E c o R I$ and Msel adapters were ligated. Finally, the resulting reaction product was diluted $3 X$ in a TE buffer $(10 \mathrm{mM}$ of Tris- $\mathrm{HCl}$ and $1.0 \mathrm{mM}$ of EDTA, $\mathrm{pH}$ 8.0). For the pre-selective amplification, $4 \mu \mathrm{L}$ of the above diluted reaction was used, together with $1 \mu \mathrm{L}$ of pre-selective oligonucleotides (EcoRI and Msel) and $15 \mu \mathrm{L}$ of the AFPL Amplification Core Mix (consisting of buffer, dNTPs, $\mathrm{MgCl}_{2}$ and DNA polymerase enzyme). The thermocycler program used for this step consisted of: $72{ }^{\circ} \mathrm{C}$ for 2 minutes (start); $94{ }^{\circ} \mathrm{C}$ for 20 seconds (denaturation); $56{ }^{\circ} \mathrm{C}$ for 30 seconds (annealing); $72{ }^{\circ} \mathrm{C}$ for 2 minutes (extension) and $60{ }^{\circ} \mathrm{C}$ for 30 minutes (End). The denaturation, annealing and extension required 20 cycles. After the cDNA-AFLP reaction, products were separated by $6 \%$ polyacrilamyde gel $(\mathrm{w} / \mathrm{v})$ eletrophoresis, which allowed the excision of differentially expressed bands observed in the resistant variety.

Seven EcoRI (GACTGCCTACCAATTCXXX) and Msel (GACTGCCTACCAATTCXXX) oligonucleotide pairs combinations were used, with the respective endings: AAC/CAG; AGG/CAT; ACT/CTA; AGG/CAA; AAC/CTG; ACG/CAG and AGC/CTA. For the selective amplification $2.0 \mu \mathrm{L}$ of the reaction products obtained through the pre-selective amplification diluted $4 \mathrm{X}$ in a TE buffer; $1,5 \mu \mathrm{L}$ of $10 \mathrm{X}$ buffer
(200 mM of Tris- $\mathrm{HCl}, \mathrm{pH}$ 8.4; $500 \mathrm{mM}$ of $\mathrm{KCl}$ ); 1.2 $\mu \mathrm{L}$ of $\mathrm{MgCl}_{2}$ at $25 \mathrm{mM} ; 1.5 \mu \mathrm{L}$ of dNTPs at $2.5 \mathrm{mM}$ (Invitrogen Corp., CA, USA); $2.0 \mu \mathrm{L}$ of Msel oligonucleotide at $10 \mu \mathrm{M}$ without fluorescent staining (Sigma Life Science); $2.0 \mu \mathrm{L}$ of EcoRI oligonucleotide at $10 \mu \mathrm{M}$ without fluorescent staining (Sigma Life Science); 1.25 U of Taq DNA polymerase (Fermentas, Lithuania) and sterile ultrapure water were used, to a final volume of $15 \mu \mathrm{L}$ (cycling in the thermocycler: 40 cycles, 10 cycles with a reduction of annealing temperature from $66{ }^{\circ} \mathrm{C}$ to $56{ }^{\circ} \mathrm{C}$ at $1{ }^{\circ} \mathrm{C}$ per step, at $56^{\circ} \mathrm{C} 30$ times, and finally a step of $60{ }^{\circ} \mathrm{C}$ for $30 \mathrm{~min}$ ). Preparation of plates and samples, electrophoresis and silver nitrate staining were performed as described by CRESTE et al. (2001).

Fragments' expression observation exclusive for the resistant variety on $6 \%$ denaturing polyacrylamide gel was possible after silver nitrate staining. These fragments were excised, resuspended in $50 \mu \mathrm{L}$ of TE buffer (composed of $10 \mathrm{mM}$ Tris- $\mathrm{HCl}$ and $1.0 \mathrm{mM}$ EDTA, pH 8.0) initially through overnight incubation at $4{ }^{\circ} \mathrm{C}$ and then at $60{ }^{\circ} \mathrm{C}$ for $2 \mathrm{~h}$, and finally, with three cycles of freezing and thawing and rapid centrifugation, in accordance with PATHAN et al. (2007). Then, the re-amplification reaction proceeded, for which a $10 \mu \mathrm{L}$ aliquot of the eluate of each fragment was used, together with the selective primers that gave rise to the respective fragments. PCR product purification was performed with the Wizard ${ }^{\circledR}$ SV Gel and PCR Clean up system kit (Promega), following manufacturer's instructions. Cloning was performed using pGEM-T Easy Vector Systems (Promega) according to manufacturer's instructions. For the alignment reaction of the product to the vector, it was used: a $75 \mathrm{ng}$ aliquot (purified PCR product), $5 \mu \mathrm{L}$ of the $2 \mathrm{X}$ alignment T4 DNA kit ligase buffer, $25 \mathrm{ng}$ of the cloning vector, $3 \mathrm{U}$ of the T4 DNA ligase kit enzyme and sterile milliQ water to a final volume of $10 \mu \mathrm{L}$. This reaction was kept at $4{ }^{\circ} \mathrm{C}$ for 17 hours. Then, recombinant plasmids were used to transform competent cells of Escherichia coli (strain DH10B) by heat shock in a water bath at $42{ }^{\circ} \mathrm{C}$ for $30 \mathrm{~s}$, and then returned to the ice. Subsequently, cells were transferred to $1.0 \mathrm{~mL}$ of SOC culture medium $(1000 \mu \mathrm{L} \mathrm{SOB}$, $40 \mu \mathrm{L}$ of glucose $20 \%$ and $40 \mu \mathrm{L}$ of $\mathrm{MgCl}_{2} 1 \mathrm{M}$ ) and incubated at $37^{\circ} \mathrm{C}$ for $1 \mathrm{~h}$ at $220 \mathrm{rpm}$. Finally, the transformed $E$. coli cells were spread on culture plates containing 2XTY solid medium, ampicillin antibiotic $\left(50 \mu \mathrm{g} \mathrm{mL}^{-1}\right), X$-gal $2 \%$ and IPTG at $100 \mathrm{mM}$. Thus, colonies containing the vector with the cloned DNA (white color) were selected and inoculated in ELISA plates containing $150 \mu \mathrm{L}$ of 2XTY medium with $8 \%$ of glycerol and ampicillin $\left(50 \mu \mathrm{g} \mathrm{mL}^{-1}\right)$, incubated at $37^{\circ} \mathrm{C}$ for $16 \mathrm{~h}$ and then stored at $-80^{\circ} \mathrm{C}$. The plasmid DNA extraction for the cloned fragment sequencing was carried out using the alkaline lysis method described by 
SAMBROOK et al. (1989), with some modifications. The samples were then submitted for sequencing on an $\mathrm{ABI}-3730 \mathrm{XL}$ equipment, following manufacturer's recommendations (Applied Biosystems, Foster City, California (CA)). DEF (Differentially Expressed Fragments) samples were sequenced and the evaluation of the quality of nucleotide sequences was performed using the Phred/Phrap/Consed (EWING \& GREEN, 1998; http://www.phrap.org) tools set. The results were observed with the aid of the Basic Local Alignment Search Tool - BLAST, to identify similarities with the sequences already deposited in public databases provided by NCBI (National Center for Biotechnology Information - http: //www.ncbi.nlm.nih.gov/). Sequence alignment in order to identify them was performed with the aid of BlastX, TBlastX and BlastN by using BLAST tool. The obtained similarities were found in the UniProtKB (http://www.uniprot.org) protein database and in the ProDom (http://prodom.prabi.fr/) protein domains database.

\section{Results and discussions}

The cDNA-AFLP technique allowed differential expression identification of 37 fragments in the 4 analyzed periods: 1, 2, 7 and 14 days after infestation. Seven initiator oligonucleotides combinations were used, which were randomly chosen for the selective amplification reactions and the combination that allowed the detection of the highest number of fragments was ACT/CTA, arranged in Figure 1.

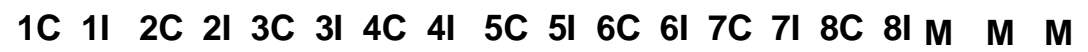

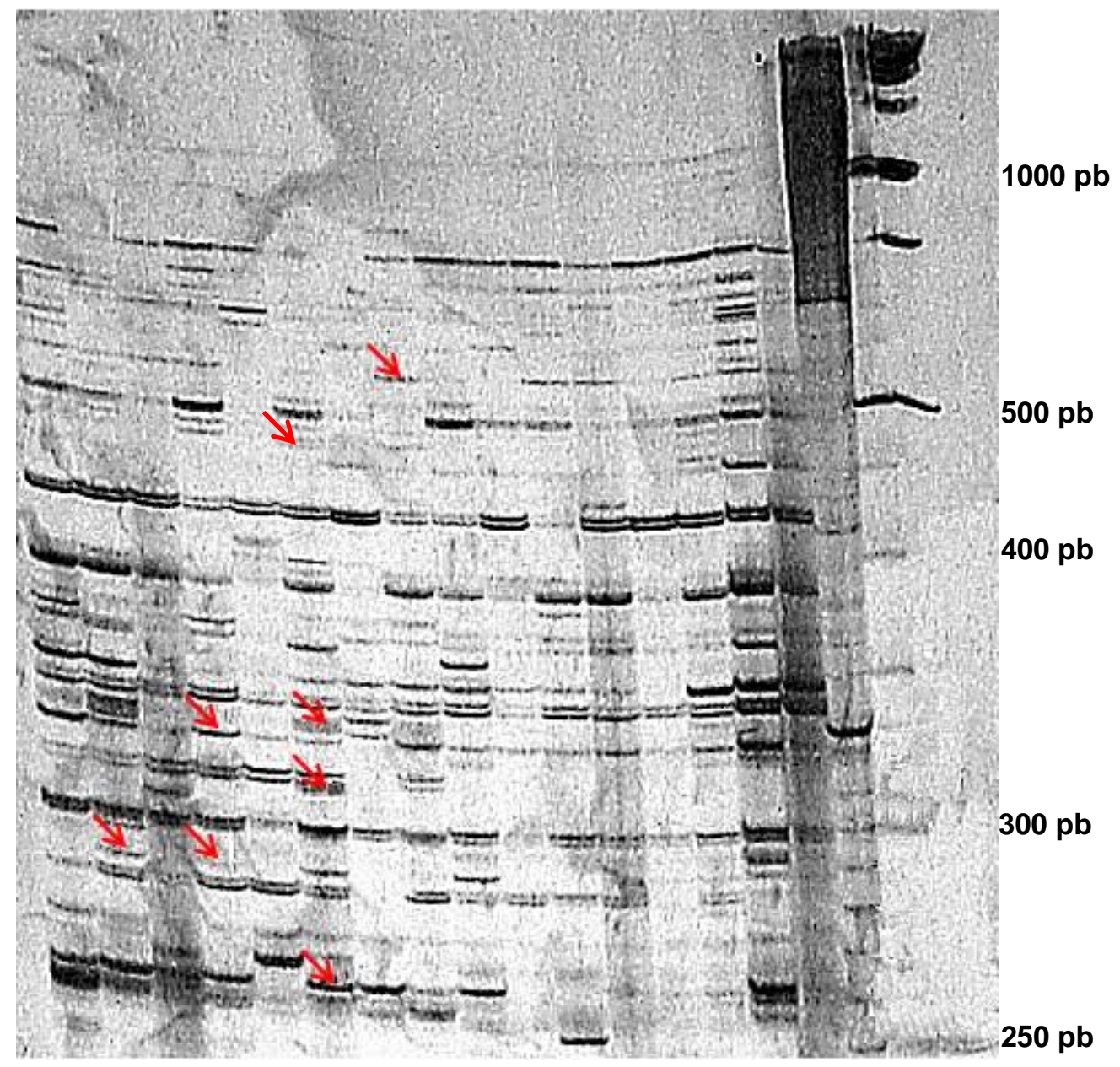

Figure 1 - Details of DEF obtained by the use of the combination ACT/CTA on 6\% polyacrylamide gel. The letters $C$ and I accompanying numbers represent the control and infested plants, respectively. The SP83-5073 variety is represented by numbers 1 (collection I), 2 (collection II), 3 (collection III) and 4 (collection IV), and SP80-1816 by the numbers 5 (collection I), 6 (collection II), 7 (collection III) and 8 (collection IV). 
Furthermore, the AAC/CTG combination was discarded from the study, as it has not allowed DEF identification. For the technique, 16 samples were used, which consisted of representative aliquots of each of the 4 collection days. After the $6 \%$ polyacrylamide gel plate electrophoresis, samples were stained, allowing DEF detection through bands visualization. We obtained $37 \mathrm{DEF}$ regarding 4 days of collection. These genes were expressed in the resistant variety and not expressed in the susceptible variety, so they were cloned and sequenced (Table 1).

Table 1 - DEF detected only in the resistant variety of sugarcane, SP83-5073, subjected to infestation by root froghopper.

\begin{tabular}{|c|c|c|c|c|c|c|}
\hline DEF & ${ }^{2}$ Combination & Size $(p b)$ & ${ }^{3}$ Access No. & Similarities & ${ }^{4}$ E-value & \%ldentity \\
\hline \multicolumn{7}{|c|}{1 day after root froghopper infestation } \\
\hline 1 & AAC-CAG & 228 & - & No similarities & _- & - \\
\hline 2 & AAC-CAG & 102 & - & $\begin{array}{l}\text { No similarities } \\
\text { SUM01-008F-C01-002.b } \\
\text { Sugarcane mature leaf }\end{array}$ & - & - \\
\hline 3 & ACT-CTA & 261 & DN194380.1 & $\begin{array}{c}\text { hybrid cultivar CoS } 767 \\
\text { cDNA clone SUM01-008F- } \\
\text { C01-002 5-, mRNA } \\
\text { sequence }\end{array}$ & $5 e-05^{\circ}$ & $\begin{array}{l}22 / 33 \\
(67 \%)\end{array}$ \\
\hline 4 & ACT-CTA & 145 & XP_002455617.1 & $\begin{array}{c}\text { Sorghum hypothetical } \\
\text { protein } \\
\text { SORBIDRAFT_03g014455 }\end{array}$ & $3 e-06^{*}$ & $\begin{array}{l}24 / 30 \\
(80 \%)\end{array}$ \\
\hline 5 & ACT-CTA & 287 & AAD22153.1 & $\begin{array}{l}\text { Sorghum pōyprotein } \\
\text { AF061282_6 }\end{array}$ & $4 e-23^{*}$ & $\begin{array}{l}44 / 71 \\
(62 \%)\end{array}$ \\
\hline 6 & ACT-CTA & 282 & XP_002448119.1 & $\begin{array}{c}\text { Sorghum hypothetical } \\
\text { protein } \\
\text { SORBIDRAFT_06g021470 }\end{array}$ & $3 e-20^{*}$ & $\begin{array}{l}57 / 60 \\
(95 \%)\end{array}$ \\
\hline 7 & ACT-CTA & 84 & - & No similarities & - & - \\
\hline 8 & AGC-CTA & 160 & - & No similarities & - & - \\
\hline 9 & AGC-CTA & 100 & - & No similarities & - & - \\
\hline 10 & ACG-CAG & 510 & _ & No similarities & _- & - \\
\hline 11 & ACG-CAG & 264 & - & No similarities & _ & _- \\
\hline \multicolumn{7}{|c|}{2 days after root froghopper infestation } \\
\hline 12 & & 368 & CA116777.1 & $\begin{array}{l}\text { SCACLR1130F11.g LR1 } \\
\text { Saccharum hybrid cultivar } \\
\text { SP80-3280. CDNA clone } \\
\text { SCACLR1130F11 5', } \\
\text { mRNA sequence }\end{array}$ & $2 \mathrm{e}-76^{\dagger}$ & $\begin{array}{c}341 / 342 \\
(99 \%)\end{array}$ \\
\hline 13 & AGG-CAA & 248 & - & No similarities & - & - \\
\hline 14 & AGC-CTA & 672 & _ & No similarities & _ & _ \\
\hline 15 & ACG-CAG & 503 & - & No similarities & - & - \\
\hline 16 & ACG-CAG & 326 & _ & No similarities & _ & _ \\
\hline \multicolumn{7}{|c|}{7 days after root froghopper infestation } \\
\hline 17 & ACT-CTA & 490 & NP_001152066.1 & $\begin{array}{l}\text { yfnA - maize hypothetical } \\
\text { protein }\end{array}$ & $4 \mathrm{e}-46^{*}$ & $\begin{array}{l}79 / 82 \\
(96 \%)\end{array}$ \\
\hline 18 & ACT-CTA & 436 & ACN26960.1 & Unknown maize protein & $3 e-92^{*}$ & $\begin{array}{c}135 / 141 \\
(96 \%)\end{array}$ \\
\hline 19 & ACT-CTA & 356 & ACN37000.1 & Unknown maize protein & $3 e-68^{*}$ & $\begin{array}{c}103 / 112 \\
(92 \%)\end{array}$ \\
\hline 20 & ACT-CTA & 282 & $X P \_002448119.1$ & $\begin{array}{c}\begin{array}{c}\text { Sorghum hypothetical } \\
\text { protein }\end{array} \\
\text { SORBIDRAFT_06g021470 }\end{array}$ & $3 e-19^{*}$ & $\begin{array}{l}56 / 60 \\
(93 \%)\end{array}$ \\
\hline \multicolumn{7}{|c|}{ Continuation } \\
\hline
\end{tabular}


Table 1 - Continuation....

\begin{tabular}{|c|c|c|c|c|c|c|}
\hline DEF & ${ }^{2}$ Combination & Size (pb) & ${ }^{3}$ Access No. & Similarities & ${ }^{4}$ E-value & \%ldentity \\
\hline 21 & ACT-CTA & 329 & CA078658.1 & $\begin{array}{l}\text { SCRLAM1009H04.g AM1 } \\
\text { Saccharum hybrid cultivar } \\
\text { SP80-3280. cDNA clone } \\
\text { SCRLAM1009H04 5', } \\
\text { mRNA sequence } \\
\text { SCRLAM1009H04.g AM1 }\end{array}$ & $1 e-29^{\circ}$ & $\begin{array}{l}53 / 63 \\
(84 \%)\end{array}$ \\
\hline 22 & ACT-CTA & 329 & CA078658.1 & $\begin{array}{l}\text { Saccharum hybrid cultivar } \\
\text { SP80-3280. cDNA clone } \\
\text { SCRLAM1009H04 5', } \\
\text { mRNA sequence }\end{array}$ & $3 e-30^{\circ}$ & $\begin{array}{l}53 / 63 \\
(84 \%)\end{array}$ \\
\hline 23 & ACT-CTA & 309 & XP_002438671.1 & $\begin{array}{c}\text { Sorghum hypothetical } \\
\text { protein } \\
\text { SORBIDRAFT_10g024070 }\end{array}$ & $7 e-08^{*}$ & $\begin{array}{l}26 / 28 \\
(93 \%)\end{array}$ \\
\hline 24 & ACT-CTA & 231 & - & No similarities & - & - \\
\hline 25 & АСТ-CTA & 232 & - & No similarities & - & - \\
\hline 26 & ACT-CTA & 528 & XP_002489173.1 & $\begin{array}{l}\text { Sorghum hypothetical prote } \\
\text { SORBIDRAFT_0014s00521 }\end{array}$ & $1 e-47^{\star}$ & $\begin{array}{l}80 / 13 \\
(58 \%)\end{array}$ \\
\hline 27 & ACT-CTA & 528 & XP_002538165.1 & $\begin{array}{l}\text { Castor bean conserved } \\
\text { hypothetical protein }\end{array}$ & $3 e-22^{*}$ & $\begin{array}{l}66 / 127 \\
(52 \%)\end{array}$ \\
\hline 28 & ACG-CAG & 633 & - & No similarities & - & - \\
\hline 29 & ACG-CAG & 1142 & - & No similarities & - & - \\
\hline \multicolumn{7}{|c|}{14 days after root froghopper infestation } \\
\hline 30 & ACT-CTA & 528 & XP_002538165.1 & $\begin{array}{l}\text { Castor bean conserved } \\
\text { hypothetical protein }\end{array}$ & $3 e-22^{*}$ & $\begin{array}{l}66 / 127 \\
(52 \%)\end{array}$ \\
\hline 31 & ACT-CTA & 312 & - & No similarities & - & - \\
\hline 32 & AGG-CAA & 177 & - & No similarities & - & - \\
\hline 33 & AGG-CAA & 132 & - & No similarities & - & - \\
\hline 34 & AGG-CAA & 98 & - & No similarities & - & - \\
\hline 35 & AGC-CTA & 608 & _ & No similarities & - & - \\
\hline 36 & AGC-CTA & 329 & - & No similarities & - & - \\
\hline 37 & AGC-CTA & 296 & _ & No similarities & _ & - \\
\hline
\end{tabular}

DEF generated from selective oligonucleotides; ${ }^{2}$ Oligonucleotides combination; ${ }^{3}$ GenBank Access Number;

${ }^{4}$ The E-value used to indicate the significance of the sequence similarity; * Alignment through TBlastX tool;

- Alignment through BlastX tool; † Alignment through BlastN tool.

Fragment 4, observed on the first day after infestation, showed similarity with a sorghum hypothetical protein called SORBIDRAFT_03g014455, whose research of its sequence against the protein database (UniProt) has not presented data on its molecular functions and cellular localization. The reference crossing against other domains and families databases demonstrated relation with transposase proteins family. It is known that these proteins are necessary for the efficient transposition in DNA, and this result can be considered an important indication of the relation of transposable elements for the resistance of this variety. It is worth noting the importance of the study of transposable elements related to stress. The transposable elements were first suggested by MCCLINTOCK (1984), who linked them to a stress response, and since then other studies with different organisms turned to investigate these elements under several conditions; such as responses to UV exposure, temperature, radiation, infection by pathogens, among others (SLOTKIN \& MARTIENSSEN, 2007). According to SLOTKIN \& MARTIENSSEN (2007), stress reactivated by these elements can generate the diversity that a species needs over evolutionary time to survive to a specific stress, so this data shows the need for further transcripts similarity studies with transposable elements and/or related proteins, once it will enable the understanding of a possible relation with the resistance status of sugarcane varieties infested by root froghopper.

Fragment 5, observed on the first day of collection, showed similarity to a sorghum polyprotein called AF061282_6. According to information in the Gene Ontology (GO), this protein is related to the biological process of DNA integra- 
tion, RNA-dependent DNA replication and proteolysis. Furthermore, it is involved with RNA binding molecular functions, RNA-directed DNA polymerase activity, aspartic type endopeptidase activity and zinc ion binding, featured in some domains, comprising: $\mathrm{RNaseH}$, integrase and aspartic peptidase. When the referred sequence was submitted against the database of protein domains (Prodom), it showed similarity with a probable retrotransposon protein of Ty3-gypsy subclass. This result complements Slotkin and Martienssen studies, showing evidence of the relation of transposable elements with the sugarcane variety resistant to attack by the root froghopper. The retrotransposons are mobile genetic elements that transpose through reverse transcription by using an RNA intermediate (KUMAR \& BENNETZEN, 1999), and can be divided into two groups: those with LTRs terminal repetitions and those which do not have it. According to KUMAR \& BENNETZEN (1999), these elements are present in a high copy number in most plants, making them the major components of plant genomes. The retrotransposons that present LTRs are divided into two groups, the Ty1-copy and Ty3-gypsy, which differ by genes order, and the Ty3-gypsy, which presented sequence similarity to $\mathrm{DEF}$, has a similar organization to the retrovirus. DEDEMO (2011) also reported similarity to this retrotransposon subclass in his study of sugarcane differential gene expression for drought tolerance, and this data allows us to associate these retrotransposons with biotic and abiotic stresses pathways.

The protein corresponding to fragment 6, recorded on the first day after infestation, has also been identified on the seventh day after infestation (Fragment 20), and it is a hypothetical protein of Sorghum graminaceous

called

SORBIDRAFT_06g021470, whose molecular functions provided by GO comprise RNA connection and nucleotides connection, working in the RNA processing biological process.

Regarding DEF similarities for the 7th day of root froghopper infestation, 7 proteins are presented. Maize hypothetical protein, corresponding to the fragment 17, called YfnA, showed similarity with amino acid permeases and, besides that, has a molecular role referred to transmembrane amino acid transporter activity. Further analysis of the sequence against protein domain database confirmed it with similarities, showing some protein domains for permeases. According to LIU \& BUSH (2006), it seems clear that, due to the large number of amino acid transporters in plants, they are functionally distinguished, based on cell substrate, tissue expression patterns, development and environment. However, knowledge of the expression of these transporter genes and how they may be related to biotic stress caused by pests in sugarcane, especially by the root froghopper, is of great importance, and nothing about it was found in the literature, compared to biotic stress studies.

For the same sampling period were also observed two fragments (18 and 19), both with similarity to an unknown maize protein (NCBI accession numbers: ACN26960.1 and ACN37000, respectively). Fragment 23 showed similarity with a sorghum hypothetical protein, SORBIDRAFT_10g024070, which is involved in the biological process of L-arabinose metabolism, a polymer constituent of the plant cell wall and it presents a glycosyl hydrolase domain of unknown function. It is known that glycosyl hydrolases cleave glycosidic connections present in polymeric structures, and that can be related to the response to several stresses, such as chitinases (GOMES et al., 2010). This result agrees with that obtained by GUIMARÃES (2007, cited by MUTTON et al. (2012)), who using the cDNA-AFLP technique in the same sugarcane varieties of this present study, infested by $M$. fimbriolata nymphs, identified using other combinations a similarity with a 389 base pairs DEF, with a class III chitinase present on Sphenostylis stenocarpa.

Fragments 26 and 27 (seventh day after infestation) presented, respectively, similarity to a sorghum hypothetical protein, SORBIDRAFT_0014s005210, and a castor bean conserved hypothetical protein, (also similar to the fragment 30). However, the molecular functions and their relations with other protein domains, for both, are not available on GO.

Among the presented DEF, some exhibited low or no similarity to the databases sequences. According to the obtained information, the DEF were categorized (Figure 2).

So it is possible to consider that $78.38 \%$ of DEF could not be classified; $18.92 \%$ of DEF are conserved hypothetical proteins and, finally, $2.70 \%$ of DEF are mobile genetic elements. The lack of similarity of the databases genes suggests that it may encode proteins that have not yet been described, which are connected with the sugarcane variety SP83-5073 resistance to $M$. fimbriolata. Furthermore, this data come to enrich the lack of knowledge about the gene expression related to the sugarcane infestation by root froghopper nymphs.

\section{Conclusions}

Differentially expressed fragments detected by comparative analysis between the transcriptional profiles of resistant (SP83-5073) and susceptible (SP80-1816) sugarcane varieties against root froghopper attack allowed the detection of differential gene expression in infestation conditions, revealing candidate genes for plant resistance in this condition. 


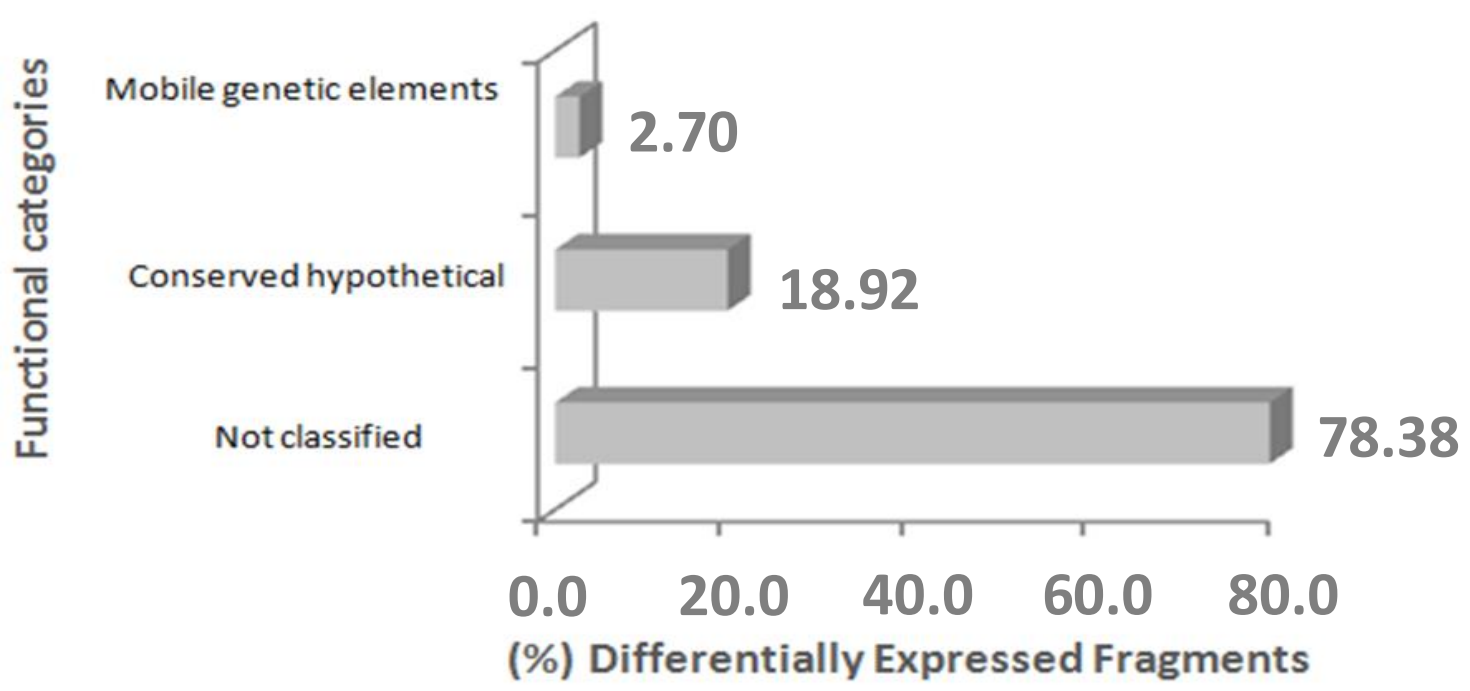

Figure 2 - Functional categorization of DEF in roots of resistant variety to attack by the froghopper, similarities obtained from UniProtKB and ProDom database.

\section{Aknowledgments}

Thanks to FAPESP and CAPES for financial support. Thanks to Prof. Dr. José Roberto Postali Parra, from the Department of Entomology and Acarology of the "Luiz de Queiroz" (ESALQ) Superior School, University of São Paulo (USP), for providing the use of his laboratory and equipment, which allowed the infestation of sugarcane varieties by root froghopper nymphs.

\section{References}

ALBA, R.; FEI, Z.; PAYTON, P.; LIU, Y.; MOORE, S. L.; DEBBIE, P.; COHN, J.; D'ASCENZO, M.; GORDON, J. S.; ROSE, J. K. C.; MARTIN, G.; TANKSLEY, S. D.; BOUZAYEN, M.; JAHN, M. M.; GIOVANNONI, G. ESTs, cDNA microarrays, and gene expression profiling: tools for dissecting plant physiology and development. The Plant Journal, Oxford, v.39, n.5, p.697-714, 2004.

ALMEIDA, J. E. M.; BATISTA FILHO, A.; SANTOS, A. S. Avaliação do controle biológico de Mahanarva fimbriolata (Hom., Cercopidae) com o fungo Metarhizium anisopliae em variedades de cana-deaçúcar e diferentes épocas de corte. Arquivos do Instituto Biológico, São Paulo, v.70, n.1, p.101103, 2003.

BACHEM, C. W.; OOMEN R. J. F.; VISSER, R. G. Transcript imaging with cDNA-AFLP: A Step-byStep Protocol. Plant Molecular Biology Reporter, Georgia, v.16, p.157-173, 1998.

CRESTE, S.; TULMANN-NETO, A.; FIGUEIRA, A. Detection of single sequence repeat polymorphism in denaturing polyacrylamide sequencing gels by silver staining. Plant Molecular Biology Reporter, Georgia, v.19, p.1-8, 2001.
DEDEMO, G, C. Estudo da expressão gênica entre cultivares de cana-de-açúcar contrastantes para a tolerância à seca. 2011. $108 \mathrm{f}$. Tese (Doutorado em Agronomia - Genética e Melhoramento de Plantas) - Faculdade de Ciências Agrárias e Veterinárias, Universidade Estadual Paulista, Jaboticabal, 2011.

DINARDO-MIRANDA, L. L. Cigarrinha-das-raízes em cana-de-açúcar. Campinas: Instituto Agronômico, 2003. 72p.

DINARDO-MIRANDA, L. L. Cigarrinha-das-raízes em cana-de-açúcar. In: SALVADORI, J. R.; ÁVILA, C. J.; SILVA, M. T. B. (Ed.). Pragas de solo no Brasil. Passo Fundo: Embrapa, 2004. p.495-516.

EWING, B.; GREEN, P. Basecalling of automated sequencer traces using phred. II. Error probabilities. Genome Research, v.8, p.186-194, 1998.

GARCIA, J. F.; BOTELHO, P. S. M.; PARRA, J. R. $P$. Biology and fertility life table of Mahanarva fimbriolata (Stål) (Hemiptera: Cercopidae) in sugarcane. Scientia agrícola, Piracicaba, v.63, n.4, p.317-320, 2006.

GARCIA, J. F.; GRISOTO, E.; BOTELHO, P. S. M.; PARRA, J. R. P.; GLÓRIA, B. A. Feeding site of the spittlebug Mahanarva fimbriolata (Stål) (Hemiptera: Cercopidae) on sugarcane. Scientia Agrícola, Piracicaba, v.64, n.5, p.555-557, 2007.

GOMES, L. P.; OLIVEIRA, C. I. R; SILVA, M. C; ANDRADE, C. T.; AGUILA, E. M. D.; SILVA, J. T.; PASCHOALIN, V. M. F. Purificação e caracterização da quitinase de uva (Vitis vinífera L. cv red globe) para a produção de quitosana a partir de quitina de camarão. Química Nova, v.33, n.9, p.1882-1886, 2010. 
GUIMARÃES, E. R. Cigarrinha-das-raízes em cana-de-açúcar: resistência genotípica e interação planta-praga. 2007. 53f. Tese (Doutorado em Agronomia - Produção Vegetal) - Faculdade de Ciências Agrárias e Veterinárias, Universidade Estadual Paulista, Jaboticabal, 2007.

KUMAR, A.; BENNETZEN, J. L. Plant retrotransposons. Annual Review of Genetics, Palo Alto, v.33, p.479-532, 1999.

LESTARI, P.; VAN, K.; KIM, M. Y.; HWANG, C. H.; LEE, B. W.; LEE, S. H. Differentially expressed genes related to symbiotic association in a supernodulating soybean mutant and its wild-type. Molecular Plant Pathology, v.7, n.4, p.235-247, 2006.

LIU, X.; BUSH, D. R. Expression and transcriptional regulation of amino acid transporters in plants. Amino Acids, New York, v.30, n.2, p.113120, 2006.

MACEDO, D.; ALVES, S. B.; VIEIRA, S. A. Seleção de isolados de Metarhizium anisopliae (Metsch.) Sorok. a Mahanarva fimbriolata (Stal, 1854) (Hemiptera: Cercopidae). Semina: Ciências Agrárias, v.27, n.1, p.47-52, 2006.

MCCLINTOCK, B. The significance of responses of the genome to challenge. Science, New York, v.226, n.4676, p.792-801, 1984.

NCBI - NATIONAL CENTER FOR BIOTECHNOLOGY INFORMARTION. Disponível em: <http://www.ncbi.nlm.nih.gov/>. Acesso em: $11 \mathrm{dez} .2012$.

PATHAN, A. A. K.; DEVI, K. U.; VOGEL, H.; REINEKE, A. Analysis of differential gene expression in the generalist entomopathogenic fungus Beauveria bassiana (Bals.) Vuillemin grown on different insect cuticular extracts and synthetic medium through cDNA-AFLPs. Fungal Genetics and Biology, v.44, p.1231-1241, 2007.
PRODOM DATABASE. Disponível em: <http://prodom.prabi.fr/>. Acesso em 13 dez. 2012.

SAMBROOK, J.; FRITSCH, E. F.; MANIATIS, T. Molecular cloning: a laboratory manual. 2.ed., New York: Cold Spring Harbor Laboratory Press, 1989. 1120p.

SILVA, R. J. N., GUIMARÃES, E. R., GARCIA, J. F.; BOTELHO, P. S. M.; FERRO, M .I. T.; MUTTON, M. A.; MUTTON, M. J. R. Infestation of froghopper nymphs changes the amounts of total phenolics in sugarcane. Scientia Agricola, Piracicaba, v.62, n.6, p.543-546, 2005.

MUTTON, M. J. R; MUTTON, M. A; MADALENO, L. L.; ROSSATO JÚNIOR, J. A. S; GUIMARÃES, E. R; RAVANELI, G. C; FERRO, M. I. T; FERNANDES, O. A. Estressores bióticos em cana-de-açúcar: reflexos quali-quantitativos na matéria prima e no processamento industrial. In: LEMOS, E. G. M ; STRADIOTTO, N. R. Bioenergia: desenvolvimento e inovação. São Paulo: Editora UNESP, 2012. Cap.12.

SLOTKIN, R. K., MARTIENSSEN, R. Transposable elements and the epigenetic regulation of the genome. Nature Reviews Genetics, Londres, v.8, n.4, p.272-285, 2007.

UNIPROT. Disponível em: <http://www.expasy.uniprot.org/> Acesso em: 12 dez. 2012.

VOS, P.; HOGERS, R.; BLEEKER, M.; REIJANS, M.; VAN DE LEE, T.; HORNES, M.; FRIJTERS, A.; PELEMAN, J,; KULPER, M.; ZABEAU, M. AFLP: a new technique for DNA fingerprinting. Nucleic Acids Research, Oxford, v.23, n.21, p.4407-4414, 1995. 